\title{
Industrial and Environmental Pressures Affecting Fante-Speaking Artisanal Fishers of Anomabo, Ghana: A Case Study
}

Dylan Clark

Portland State University

Follow this and additional works at: https://pdxscholar.library.pdx.edu/mcnair Let us know how access to this document benefits you.

\section{Recommended Citation}

Clark, Dylan (2013) "Industrial and Environmental Pressures Affecting Fante-Speaking Artisanal Fishers of Anomabo, Ghana: A Case Study," PSU McNair Scholars Online Journal: Vol. 7: Iss. 1, Article 11. https://doi.org/10.15760/mcnair.2013.1 
Portland State University McNair Research Journal 2013

Industrial and Environmental Pressures Affecting Fante-Speaking Artisanal Fishers of Anomabo, Ghana: A Case Study

\author{
Dylan Clark
}

\title{
Faculty Mentor:
}

Dr. Kofi Agorsah

Clark D. Industrial and Environmental Pressures Affecting Fante-Speaking Artisanal Fishers of Anomabo, Ghana: A Case Study. Portland State University McNair Scholars Online Journal, Vol. 7, 2013 


\title{
Industrial and Environmental Pressures Affecting Fante-Speaking Artisanal Fishers of Anomabo, Ghana: A Case Study
}

\author{
By: Dylan Clark \\ Faculty Mentor: Dr. E. Kofi Agorsah
}

\begin{abstract}
:
A great deal of literature exists regarding the global fisheries crisis. However, the human element has been largely overlooked. This study seeks to understand the relationship that traditional Fante-speaking peoples have with oceanic resources. Interviews with artisanal fishers, trades-women, and influential elders from the coastal village of Anomabo in the Central Region of Ghana were conducted over a six-week period. Interviews revealed the degree to which artisanal fishers compete with industrial fleets (both domestic and foreign), the nutritional and economic importance of the artisanal industry as well as the cultural practices embedded within maritime subsistence activities. Industrial fisheries threaten global marine stocks, and with them, the survival of cultures tied to the sea. This study suggests a necessity for swift policy change in order to ensure the health of West African marine stocks, and to protect the nutritional, economic, and cultural basis of Fante-speaking communities.
\end{abstract}

\section{Introduction:}

People have been fishing the rivers and lagoons of Ghana since long before Europeans documented these practices in the fifteenth century. However, Robin Law (1989) has suggested that marine fishing and coastal trade by sea developed after the arrival of European traders. Due to the lack of natural harbors in West Africa, Europeans hired fishermen as so-called "canoe men" to transport people and goods from their ships across rough surf to the beaches and vice versa. The coastal populations already had dugout canoes, but since these canoes had to be modified in order to get them across the surf, Law (1989) supposed that canoes were not used for seafaring earlier. Regardless of when the local populations took to the sea, they soon mastered maritime subsistence and continue fishing to this day.

Daily life in the Fante-speaking village of Anomabo, Ghana revolves around the artisanal fishery. Early every morning, in the grey of pre-dawn light, the seafaring men of Anomabo gather to brave the ocean and land the catch. Many of the men have worked on boats from the time they were young boys and have only known the life of a fisher. Education is a luxury and few of the men ever attended school. An unforgiving ocean was their classroom and their kin with whom they fish were their teachers. In their youth they gained detailed knowledge of the sea: a tint of red to the water means herring are below; a flock of gathering seagulls signifies rich waters. They learned how to read the weather and endure storms that cannot be avoided. As boys they developed balance on canoes perpetually bullied about by tumultuous waves. They learned the different types of nets to use throughout the season and where to go in order to find the richest stocks. Few of the men can recall their age for certainty, but all remember fishing as soon as they were old enough to be of use. They are men forged by the adversity of their environment.

Fante fishermen are proud of their maritime prowess, but their life is not one that they truly want for themselves or their sons. Jorion (1988) wrote that "no one ever becomes a fulltime maritime fisherman other than under duress"(p. 12. Fishing is hard and unpredictable. One season the fishers may catch enough to get by; another season they may not. But their 
options are limited. From an early age these men mastered the seas, but their skills are restricted to riding raging waters and harvesting fish. Few fishermen can read and even fewer can speak English. They were the children of fishers, most of them too poor to attend school - so they took to the sea. Evidence from Ghanaian living-standards surveys, which employ expenditure level data, consistently categorize the coastal fishing communities as among the poorest in the country (Marquette et al., 2002). It is likely that the sons and nephews of the fishers will join them on the boats one day, just as they joined their fathers and uncles before them. This is the nature of life for Anomabo fishermen. Hard men lead hard lives in order to make it in an unforgiving world. Despite these hardships, the Fante have survived and thrived by exploiting variably abundant marine resources.

The marine ecosystem of the Gulf of Guinea, within which coastal Ghana falls (the area between Cote d'Ivoire and the Republic of Benin in West Africa), is characterized by seasonal upwelling (Fig. 1). During certain periods of the year, sea-surface temperatures in the Gulf fall, triggering upwelling toward the surface of cold nutrient-rich water. During this upwelling, the production of phytoplankton and zooplankton rise considerably, creating greater seasonal availability of fish during the upwelling period (Marquette et al., 2002). Coastal communities which exploit and depend on this ecosystem have developed a tradition of strategic migration in order to maintain their resilience to this cycle (Perry \& Sumaila, 2004). Fante artisanal fishers migrate to productive areas in order to best exploit seasonal stocks and unsaturated markets. The search for prosperous waters has resulted in the distribution of Fante communities throughout West Africa (Njock \& Westlund, 2010).

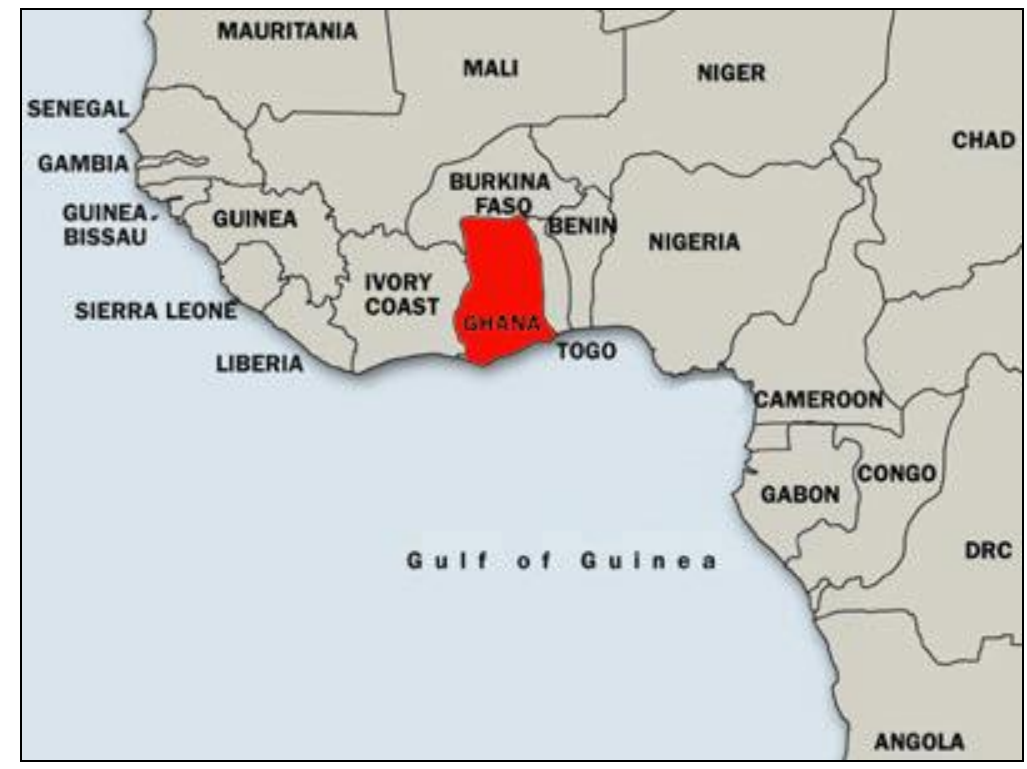

Figure 1.

Fishing is a community effort among the Fante of Anomabo. During the abundant "major" season one can easily observe the various roles that serve to support the artisanal fishers. Trades-women barter for their share at the beach market. Ocean front shacks of motor repairmen bustle with activity. Aged net-makers, once fishermen themselves, toil with broken bodies to make and repair nets. Chainsaws roar and axes hack as canoe craftsmen work tirelessly from dawn until dusk; carving out massive canoes from primeval trees. Canoes are expensive and few fishers have the means to purchase their own craft. Instead, a canoe owner provides the equipment and boat, and in return receives two-thirds of the profits. The canoe owners can be male or female and many prosperous trades-women 
invest in canoes. Female fish traders are well known innovators, entrepreneurs, and capitalists in Ghana's artisanal fishing industry (Walker, 2001). Throughout the abundant months of the major fishing season the community experiences growth. More shops open and houses can expand. In the words of one old fisherman, "without fishing, there would be no Anomabo". Anomabo waxes and wanes with the abundance of fish. And if marine stocks were to wane into oblivion so too would the Fante.

This study seeks to illuminate certain untold truths regarding the artisanal fishers of Ghana. The industrial fishing industry is operating at an unsustainable level. The Gross malpractice of commercial fisheries not only threatens West African fish stocks, but also the people who depend on said resources. The Fante-speaking people of Anomabo represent a microcosm of a larger culture. This culture will suffer tremendously if international fisheries do not pursue more enlightened practices.

\section{Background:}

Fante long-distance and long-term fisheries migration to countries such as Cote d'Ivoire, Liberia, Guinea, Sierra Leone, Senegal, Togo, Benin, and Nigeria have been well documented for over 200 years (Marquette et al., 2002). In 1721, chronicler William Bosman writes that there were thousands of Fante fishermen who, in addition to fishing, used their canoes in trade along the coast (Christensen, 1977). Between the late 1700s and mid-1800s, the Fante introduced sea-fishing to other coastal populations (i.e. Ga-Adangbe and Anlo-Ewe), who were mainly farmers supplementing their diet with fish from lagoons and rivers (Lawson \& Kwei, 1974). In the twentieth century, mechanized shipping routes distributed Fante fishers extensively; migrants reaching as far as Mauritania to the north and Congo to the south in order to fish areas with under-exploited marine resources and exploit markets unsaturated with fish (Delauney, 1991; Boujou, 2000).

Among Fante fishers, seasonal migration to a large extent is resource driven, while longterm and circular migration tends to be less dependent on resources than on economic and political conditions (Overa, 2001). Fante fishermen and fish traders migrate to maximize profits. The primary goal is to invest these savings in their home town to enhance the wellbeing of their ebusua (matrilineage) as well as their own personal prestige. As a result, most of the ebusua fie (lineage or family houses) in Fante villages have been built in a gradual process over several years - by networks of oscillating family members periodically returning from one or several migrant destinations, usually retiring after long careers in the house they have helped to build (Overa, 1998). At certain stages of one's life, migration can be seen as a rite of passage to becoming a professional fisherman. (Overa, 2001). Extensive migration has distributed Fante-speaking people throughout West Africa, but a strong bond to ones ancestral home and clan (ebusua) persists. Migrant fishermen and traders often have their personal name and the name of their home tattooed on their forearm or underarm in order to ensure they are returned home in case they die or fall sick while away (Overa, 2001). Irrespective of spatial distribution, migrant Fante communities maintain their identity and sustain their fishing culture.

The economic benefits and extent of Fante-speaking Ghanaian migration began to deteriorate with the advent of industrial fishing in West Africa. The first Ghanaian industrial fishing trawlers were acquired about five decades ago, principally for fishing in productive, if distant waters of countries such as Angola and Mauritania. Domestic Ghanaian fisheries enjoyed a brief period of success in distant waters before global political factors resulted in their collapse. Ghanaian vessels were excluded from foreign waters, and forced to begin operating domestically when, in the mid-1970s, countries claimed 200 mile Exclusive Economic Zones (EEZ) (Koranteng \& Pauly, 2004). Major Ghanaian fishing companies such as Mankoadze Fisheries, Ocean Fisheries, Commodore, Obuorwe and Obedru, which 
flourished throughout West Africa in the 1960s and 1970s, either ceased operation or transitioned to importation and retail (Atta-Mills et al., 2004). In contrast to the collapse of domestic Ghanaian fisheries, foreign fleets have consistently expanded.

Ever increasing global demand for seafood products has stimulated the growth of foreign fisheries efforts throughout West Africa. In the past 50 years, the Gulf of Guinea's commercial marine fish landings (catches) increased from approximately 600,000 tons of fish extracted in 1950 to more than 4.5 million tons caught in 2000, by fleets as far away as China and Japan (FAO, 2000). European Union (EU) fleets are the largest presence in West Africa and operate within the EEZ of several West African nations. Reports indicate that authorized EU vessels in 1996 took a record 4.5 million tons (Kaczynski \& Fluharty, 2002). Despite such massive and arguably unsustainable landings, many European fisheries would be unprofitable if not for EU subsidies which cover up to $80 \%$ of the costs of long-distance fishing (Acheampong, 1997). These subsidies enable more foreign fleets to operate in West African waters and forces artisanal fishers to compete with considerable commercial efforts. The consequences of such massive fishing levels has been a reduction in harvest landings for local fishing communities (Atta-Mills et al., 2004), and depleted commercial harvests among foreign fleets (Alder \& Sumaila, 2004). Marine resources are dwindling on a global scale and the phenomenon has been quantified through trophic level analysis (Pauly et al., 2005).

In marine ecosystems, the mean trophic level of fish communities in a given ecosystem decreases when fishing activities are intense (Christensen, 1998; Pinnehar et al., 2002). Trophic levels (TL) are determined by the degree to which an organism feeds on producers (e.g. Skipjack Tuna has a TL of 4.3, while phytoplankton has a TL of 1 ). Important to note is that in the sea, high TL organisms tend to be larger (typically three to four times in terms of body length) than their prey (Ursin, 1973), and need more time to reach maturity and reproduce (Denney et al., 2002). This makes high TL organisms very susceptible to overfishing (Sadovy \& Cheung, 2003). Declining catch trophic levels are symptomatic of socalled "fishing down the marine food web" and describe the situation where top predators and other larger species are overfished, resulting in fishers shifting their efforts to smaller and more abundant species to maintain catch levels (Pauly \& Watson, 2003). Valtysson and Pauly (2003) conclude that, given the current technical ability to catch whatever marine species are abundant within an ecosystem, and the fact that large fishes are usually more valuable than smaller fishes, increased landings of fishes with lower TL imply a reduction of the abundance of the higher TL species. Or phrased differently, non-sustainable fishing should manifest itself, at the ecosystem level, in a gradual shift of mean TL towards lower values.

On a global scale, the rate of TL decline has mostly increased since the 1950s, with the strongest rate of decline in the 1980s. Global fisheries were operating, on average, at a TL of 3.37 in the early 1950s; now their mean TL is 3.29, but was as low as 3.25 in 1983 (Pauly et al., 2005). Trophic level analysis has also been applied at the regional level in West Africa. Results from a study concerning the demersal fish community in Senegal and Guinea displayed a decline in the mean trophic level, correlated in time with a well-known increase in fisheries efforts (Laurens et al., 2004). Extensive research and strong lines of evidence provided by the researchers above conclude that the global fisheries crisis is a reality.

The ecological impact of increased catches over the past 50 years has not been offset by significant economic gains in West Africa. Kaczynski and Fluharty (2002) found that very little of the observed landed values (usually less than $10 \%$ ) actually remained in West Africa. The little that remained did not trickle down to coastal communities to provide direct 
or indirect employment, increase overall economic growth, or social benefits as a result of fish processing and storage facilities. Many fishers in Ghana have actually become poorer as the landed values from their fisheries have increased (Atta-Mills et al., 2004)

Although foreign fishing fleets have been able to feed the demand for marine resources in many regions of the world, western African countries with significant fish resources such as Senegal, Morocco and Guinea have felt the impact through depleted fish stocks, struggling domestic fishing industries, fleet overcapacity, inadequate subsidies, inequitable access, and struggling artisanal fleets (Iheduru, 1995; Kaczynski \& Fluharty, 2002). Countries with comparatively low resources such as Ghana and Nigeria have dealt with declining fisheries and higher priced, lower quality, or less desirable imported fish (Atta-Mills et al., 2004). Ghana's fishing industry has been particularly impacted by international fisheries pressure. In 1992, there were more than 500,000 Ghanaian fishers employed, representing $2.5 \%$ of the population or $20 \%$ of the total labor force (IOC, 1997). By 1997 , only 400,000

fishermen were active in the industry (FAO, 1998). It appears that foreign fleets extract the majority of marine resources and West African fisheries suffer the consequences.

Despite dwindling stocks, artisanal Fante fish landings have remained relatively stable over the past twenty years. In fact, artisanal catches have increased overall, even though the Food and Agriculture Organization of the United Nations (FAO) has long considered Eastern Central Atlantic fisheries to be fully or overexploited (FAO, 1997). Ghanaian canoe fishers have adopted a variety of strategies to compensate for diminishing fish stocks. Fante fishers have adapted by "fishing harder", such as exploring other areas (deeper waters and further offshore), migrating to distant fishing grounds, and supplementing the main catch with alternative species. Alternative species often include demersal fishes; however, this may no longer be as option as demersal populations go into decline (Koranteng, 2001). The mainstay sardine catch (Sardinella aurita) has also been supplemented by anchovies, mackerel, and a second species of sardine (Sardinella or S. maderensis). Another reason for the landings stability is an increased use of small mesh-size nets, dynamite, and poisons. The use of dynamite in Ghana's fishing sector is thought to be ubiquitous, but concentrated mainly during the bumper or "minor" fishing season (Awity et al., 1996). Laws against dynamiting, and other harmful practices, have proven ineffectual against local fishers. It would appear that Fante fishers are incapable or unwilling to transition to other sectors, even in the context of deteriorating resource availability, and will employ any means available in order to survive.

Villages lining the west coast of Africa rely on fishing both financially and nutritionally. Ghanaians derive $68 \%$ of their animal protein from fish, and of this, $90 \%$ comes from artisanal marine capture fisheries (FAO, 1998). Observations of the economic, nutritional, and social impacts of commercial fishing suggest a trend of environmental exploitation without consideration for the local populous (Atta-Mills et al., 2004). Declining stocks, as well as declining trophic levels, endanger the food security of people who rely directly on these stocks for subsistence and the generation of income (Alder \& Sumaila, 2004). The livelihood of Fante people is inextricably tied to fishing, and as fish populations plummet, malnutrition en masse and economic fallout loom.

\section{Materials and Methods:}

Personal interviews, accompanied by an interpreter, of 16 artisanal fishers, 15 tradeswomen, and 10 elders from the village of Anomabo, Ghana were conducted over the course of six weeks. Survey questions were constructed in advance for both fishers and traders respectively. Open ended interviews were administered to elders allowing for a narrative flow to the dialogue. Participant elders were presented with aromatic schnapps, a traditional 
gift for chiefs, as a show of cultural understanding and respect. All participants were compensated with $2 \mathrm{GH} \square$ ( $\sim 1$ US).

Ghanaian culture defines the activity of getting into a canoe and fishing as a strictly male domain. Because of Ghanaian cultural norms, all participant fishers were fisher-men. The participants ranged in age from 18-65 (though many of the men were unsure of their exact age), and each individual reported supporting, on average, eight individuals (Table 1). All the men interviewed are full-time fishers with no other substantial source of income, reportedly beginning their fishing careers between the ages of 7-9.

Artisanal target species were recorded by their local Fante designation. Locally targeted species were indentified in order to determine the competition status among commercial and artisanal fishers. The harvest seasonality of artisanal fishermen was recorded in order to determine variability in the fisheries competition status throughout the year. Fishing capabilities were recorded regarding netting types, locations, and technologies (preservation, motors, etc.).

Fish-trading and retail is considered an exclusively female domain. Because of Ghanaian social norms, all participants were trades-women. The participants ranged in age from 2070 years of age and each individual supported, on average, nine individuals (see Table 1). All participants interviewed were primarily involved in the fish trade, though many had secondary sources of income that provided support throughout a period known as the "lean" season.

Traders reported the preferred town and suppliers of fish. Participants provided the cost of fish at the time of purchase. From the reports a clear understanding is gained of where the fish trade begins both geographically and economically. Trades-women reported information on the extent of the trade network and the inflation of prices as the fish traveled. Questions regarding the extent of the trade network as well as the inflation of prices were intended to reveal the availability and value of artisanal fisheries products at distant markets. The reported costs associated with transportation and processing of products, and information on the final price of the fish, reveal the financial gains of coastal fish-traders.

Participant elders include chief fishermen (apofohene), fish-trader chiefs (konkohene), and family elders (nananom). Qualitative ethnographic observations and narratives of religious traditions, myths, and festivals were recorded with the intent of revealing the cultural significance of maritime subsistence.

Table 1. Demographics of participants in the present study.

\begin{tabular}{lcccccc}
\hline Occupation & $N$ & Mean Age & Median Age & Age Range & Mean Support & Median Support \\
\hline Fisherman & 16 & 28 & 32 & $18-65$ & 8 & 8 \\
Tradeswoman & 15 & 34 & 45 & $20-70$ & 9 & 7 \\
\hline
\end{tabular}

\section{Results:}

Target Species and the Industrial Impact: Data collected in this study revealed that every artisanal target species is either commercially targeted or a major registered by-catch (Table 2). By-catch species can be dramatically impacted by fisheries efforts. In The Gulf of Guinea, demersal resources (a typical by-catch) declined 50\% between 1991 and 1995, with some species, such as croakers, threadfins, and sickle fish, considered to be overexploited (FAO, 1997). In the absence of by-catch limitations, shrimper-trawlers can use nets with authorized mesh size for shrimp $(25 \mathrm{~mm})$ rather than finfish $(65 \mathrm{~mm})$ and 
take whatever enters their nets. The by-catch proportion harvested by industrial shrimp trawlers can be as high as $90 \%$ (Kaczynski \& Fluharty, 2002). Fante names of artisanally landed fishes were translated into scientific nomenclature and examined alongside commercial fisheries data. Translations and commercial data were provided by the Ghanaian Fisheries Ministry of Cape Coast.

Table 2. Artisanal Target Species and Commercial Harvest Status.

\begin{tabular}{|c|c|c|c|}
\hline Fante Name & Common Name & Scientific Name & Status \\
\hline \multicolumn{4}{|l|}{$1-10$ N.M. } \\
\hline Ebue & - & Brachydeuterus auritus & By-catch \\
\hline Nkanfona & - & Illisha africana & By-catch \\
\hline Niantimera & - & Drepane africana & By-catch \\
\hline Ebueakowa & - & Brachydeuterus auritus subsp. & By-catch \\
\hline Silver fish & Silver fish & Trichiuridae & By-catch \\
\hline Ekan & - & Pseudotolithus senegalensis & Target \\
\hline Edue & - & Sphyraena & Target \\
\hline Small Herring & Small Herring & Sardinella auritus & Target \\
\hline Soul & Soul & Cynoglossus monodiae & Target \\
\hline Shrimp & Shrimp & Palaemonidae & Target \\
\hline Crab & Crab & Callinectes amnicola & By-catch \\
\hline Lobster & Spiny Lobster & Palinuridae & Target \\
\hline Akasaankasa & - & Polynumidae & Target \\
\hline \multicolumn{4}{|l|}{$10-40$ N.M } \\
\hline Large Herring & Large Herring & Sardinella auritus & Target \\
\hline Red Fish & - & Pagrus aurigae & Target \\
\hline Edei & Yellow-fin tuna & Thunnus albacares & Target \\
\hline Ibur & - & Thunnus sp. & Target \\
\hline Wodziyede & - & Thunnus sp. & Target \\
\hline Epae & Mackeral & Carangidae & Target \\
\hline Tunner & Skipjack tuna & Katsuwonus pelamis & Target \\
\hline Saffor & - & Scomberomorus tritor & Target \\
\hline Mackeral & - & Scomber japonicus, Scombeomorus tritor & Target \\
\hline \multicolumn{4}{|l|}{$50+$ N.M. } \\
\hline Shark & - & Sphyrna zygaena & By-catch \\
\hline Dolphin & - & & Not Targeted \\
\hline \multicolumn{4}{|l|}{ Non-specific } \\
\hline Safur & Mackeral & Scombeomorus sp. & Target \\
\hline Ebur & Mackeral & Scombeomorus sp. & Target \\
\hline Wodziyede & Mackeral & Scombeomorus sp. & Target \\
\hline Assisi & - & Hemiramphidae & By-catch \\
\hline Amoni & Anchovy & Engraulidae & Target* \\
\hline
\end{tabular}

N.M. = Nautical Mile Zone

* Bait for Tuna Companies

No foreign commercial fisheries are officially allowed to operate in Ghana due to Fisheries Act 625 (2002) which excludes foreigners from operating fishing vessels in Ghanaian waters. However, Act 625 allows for joint ventures in tuna fisheries; thus, foreign fleets exist in the local tuna industry, mainly comprising of Korean co-operatives. Industrial trawlers are allowed to go into high purchase arrangements with foreigners to acquire vessels and also employ non-Ghanaians. This arrangement has allowed many Chinese entrepreneurs into the sector with minimal integration into the domestic economy. The Chinese industrial trawlers target small pelagics, mainly Sardinella spp., and several demersal species, mainly Sparidae, Haemulidae, Lutjanidae, Polynemidae and Serranidae.

The operation territory of Ghanaian artisanal fisheries overlap that of commercial fleets. With the exception of fishing for tuna, which occurs from near-shore to the high-seas, all 
important fisheries in Ghana take place within the coastal zone (Koranteng, 1998). Artisanal fishers have unlimited access to waters along the Ghanaian coast. Industrial fleets are excluded between the coastline and the 30-meter isobath or 6 nautical miles offshore, whichever is further. This is intended to reserve resources for artisanal fishers and the coastal populations. However, the reserve zone is not respected by many commercial trawlers. It was reported by local fishers, and substantiated with personal observation, that industrial trawlers regularly trespass near shore after dark (when their call signs cannot be seen and subsequently reported).

Seasonality and Competition Variability: Seasonal variability in fisheries resources along the coast of Ghana are dominated by upwelling, which has two peaks: December to February (the "minor" season) and July to September (the "major" season) (Cury \& Roy, 2002). Fante artisanal fishers are heavily dependant on migratory herring (Sardinella aurita), the availability of which is dictated by the nutrient rich upwelling currents.

Herring stocks reach Ghanaian waters in late June and commence the major fishing season. Competition between artisanal and commercial fisheries is at its lowest point throughout the major season due to the high availability of Sardinella and the low commercial value of herring. Though herring is a major registered by-catch of tuna fleets and the target species of industrial trawlers, the impact on artisanal fishers is reportedly inconsequential. The increased abundance in resources does not completely alleviate tensions. Canoe fishers report issues of frequent illegal near-shore trespassing by commercial tuna vessels, which pursue stocks feeding on herring. The tuna vessels reportedly destroy artisanal netting and scatter fish.

The "minor" fishing season in December-January is associated with relatively abundant anchovy stocks. Followed by the "lean" season in February through May; characterized by the extended absence of abundant migratory resources. During the lean season competition between artisanal and commercial fishers is at its highest. The target species of local canoe fishers and foreign fleets alike are large tuna and demersal species. Tuna remain in Ghana year round, but are only targeted by artisanal fishers in the absence of preferred migratory herring and anchovy stocks. Tuna tend to remain far offshore, thus making it difficult for canoe fishermen who lack strong motors or onboard preservation to target tuna stocks. Because of rocky substrates, trawling below $75 \mathrm{~m}$ depth is unsafe, increasing the difficultly involved in targeting demersal species in Ghana (Koranteng, 1984). It is reported that average artisanal landings can fall from 200 pans of fish in the major season to 2 pans in the lean season (Nicholas, 1999).

Table 3. Seasonal Variability in the Artisanal Target Species

\begin{tabular}{lll}
\hline Fishing season & \multicolumn{1}{c}{ Months } & \multicolumn{1}{c}{ Target species } \\
\hline Lean & February-May & Tuna and demersal species \\
Major & June-September & Herring \\
- & October-November & Tuna and demersal species \\
Minor & December-January & Anchovy \\
\hline
\end{tabular}

Fante Fishing Technology: Artisanal Fante fishers take to the seas in canoes that range in size from 12 to 15 feet in length, and four to eight feet in width. The canoe base is carved from a single tree, usually a soft timber known as wawa, with raised planking added to the sides (Marquette et al., 2002). At the beginning of the "major" season, the village of Anomabo is filled with the roar of chainsaws tearing into wood and the methodical "thwackthwack-thwack" of carvers shaping canoe hulls. After the base is finished, wooden planking is added to the hull of the canoe; raising its sides and making it sea worthy. The canoes capsize easily and the side planking leaks and splits when battered by the fury of open seas. 
Despite obvious disadvantages the canoe form persists. The design is simple, cheap, and easily repairable. Once manufactured, fishing crews can easily maintain a craft for years.

In 1959, Ghana's Ministry of Agriculture began experimenting with attaching outboard motors to traditional fishing canoes, and a government loan scheme was introduced to enable fishermen to finance new motors (Kwei, 1961). The governments motor-loan scheme ended swiftly in economic disaster and was not reinstated (Christensen, 1977). Today, even in the absence government subsidies, most canoes are equipped with outboard motors. The price of the engine, as well as the cost gasoline and regular maintenance, represents a tremendous investment However, the technology enables fishers to go further out to sea and land greater harvests- rendering engines a necessity. Fishers reported almost exclusively the use of a small 40hp Yamaha model. The model is reportedly selected for its reliability, fuel efficiency, and mechanical simplicity.

With the advent of outboard motors within the artisanal industry, canoes grew from an average of 25 to 40 feet in length, and nylon purse seine nets were adopted. These nets can reach lengths of over 400 yards and have a mesh size of .75 inches, compared to the formerly popular gill nets, which were made of cotton and had a mesh size of 1 to 1.75 inches. Purse-seines capture all types of fishes, regardless of size and species.

Improvements in technology resulted in tremendous artisanal catch increases, and then, decreases as stocks deteriorated (Koranteng, 1989).

\section{Common Artisanal Harvest Strategies/Nets and Target Catch:}

- Adii Net- Herring

- Ahwea Net- non-specific

- Wakye Net- Herring, Tuna, Mackerel (dolphin as a common by-catch)

- Tenga Net- Red fish

- Abbo Net- Crabs and shrimp

- Libia (straight cast during daylight) Net- Herring

- Sieve (circle cast w/lighting system) Net- Herring

- Asabil Net- Cassava fish

- Mpaku Net- large tuna (sharks as a common by-catch)

- Hooking- non-specific

- Land Trawling (fishers drop a net at sea, with lines left on shore, and a large group hauls in the catch from on land) - non-specific

- $\quad$ Lighting systems- this method is designed to capture herring. The fishers go out at night and shine lights into the water. The fishers report that the herring appear as "diamonds" in the water. Once spotted, the fishers encircled the schooled fishes (which are attracted to the light) with netting and haul in the catch. Lighting systems have only emerged in the last five years.

- Dynamiting- typically only utilized in the "minor" season. Dynamiting is highly frowned upon and typically only used in the "minor" fishing season.

A coat of paint is typically all that preserves the valuable canoe base against deterioration. Because the wood is untreated, canoes must be removed from the water to dry and make repairs. In order to land canoes, Fante fishers rely on simple log-rollers and collective physical power. The fishermen ride surf as far onto shore as possible. From there, most of the crew takes hold of ropes running from the bow of the craft while a few fishers push from the stern. A chant is called out by the captain as the fishers ready themselves. "AHHHHHOE-BRA, ah- hoe-bra, AHHHH-HOE-BRA, ah-hoe-bra, AHHHH-HOE-BRA, ah-hoe-bra" meaning: "COME HERE! Come here". It is said that the chant grants the men mystical strength as they repeat this chant which recalls the ancestral warrior solidarity known as Asafo. The spiritual value of the chant is immeasurable, but the rhythm of the song 
undeniably brings the fishers strength into sync and makes landing the massive canoe that much easier. While out at sea, the same kind of chanting is used to draw up nets laden with fish from the depths. Where a wench and engine are used on industrial craft, the artisanal fishers rely on ancestral chants and raw physical power.

Fishers prefer to land at their home village where friends and kin eagerly await the catch. Other factors also draw fishers to a given port. Traders will not buy spoiled fish, and distance combined with lack of preservation technology severely limits the mobility of canoe fishers. Due to the absence of onboard preservation fishers rarely stay out more than 24 hours, and usually return to the nearest port available. Most canoes are equipped, at best, with buoyant metal lockers that ensure the haul is not lost in the likely event of capsize. Fish-lockers can be filled with ice, but the nearest ice factory to Anomabo is $40 \mathrm{~km}$ away and the cost is an unwelcome expense. The locker is typically filled, and occasionally refilled, with cool sea water to preserve the catch. The capabilities of canoe fishers stand in stark contrast to industrial fleets, which possess advanced onboard processing and storage facilities.

Women and the Artisanal Fish Trade Network: The morning hush begins to dissolve as the beach comes alive. The ocean breeze is heavy with the scent of fresh fish and the rich sound of deep voiced fishers chanting. Children brawl and play, fishers chant, and traders barter for their share of fish alongside countless interlopers. The growing crowd is a churning mass of sound, color, and chaos. The scene looks somewhere between a riot and a party. This is the beach fish market of Anomabo, and this is where the artisanal fish trade begins.

The women prefer to buy from close kin or fishers from their resident village. Often, a fishtrader will buy exclusively from her husband in order to ensure the least possible overhead and a steady income for the family. When trades-women lack fishers as close kin they will strive to buy directly from fishermen. The moment fish leave the boat, the price rises and the potential profits dwindle. Trades-women are well versed in their profession and always seek the best possible price.

A trader will typically buy fish by the "pan". Pans are large metal basins that are filled to the brim with fish. Traders will then either sell the fish fresh in town or to nearby interior villages. Fresh fish can fetch a decent price in the protein deficient back country. But, isolated villages inland are hidden in dense forest and can be found only by traveling on unkempt, extremely crude, dirt roads. It is difficult to transport fresh fish to isolated villages and the impoverished population can purchase only limited amounts. Such factors make it easier for trades-women to preserve and transport fish to large markets.

The preservation method of choice is smoking. Other methods include salting and drying. Salting is not commonly used do to the high price of salt, and drying is made difficult by insects. Additionally, smoking is said to enhance the flavor of fish and make the product more desirable. Once processed, fish are transported to distant markets where they can fetch a much higher price. A basin of fresh fish can be purchased and processed for 100$120 \mathrm{GH} \square$ and sold for 150-190GH $\square$, depending on the market. The Anomabo traders reported trading to markets as far away as Ho to the West, Akrodi to the east, and Kumasi to the North (Fig. 2). 


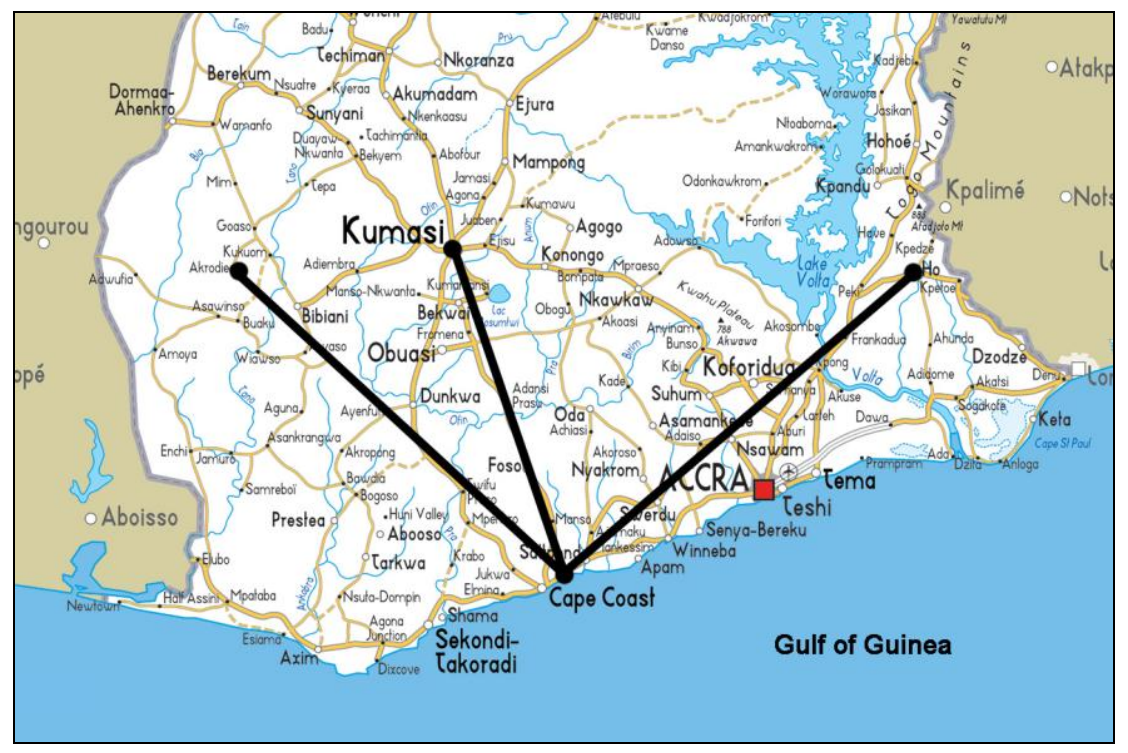

Figure 2.

Throughout the lean season many of the women turn to alternative sources of income. The sell of rubber-wares, soap, cooking utensils, etc. provides income during tough times. The traders reported that a pan of fish, which could be bought for $100 \mathrm{GH} \square$ in the major season, will cost in excess of $200 \mathrm{GH} \square$ in the lean season. The extent of the fish trade network is reportedly reduced during the lean season in order to cut costs and keep prices down. Protein is a precious and rare commodity inland, but the price of fish cannot be excessive if trades-women intend to sell.

The nutritional importance of the Fante trade network cannot be overstressed. Fish is the primary source of animal protein in West Africa, with per capita consumption of approximately $22 \mathrm{~kg}$ annually (FAO, 2004). As stated earlier, the artisanal industry is responsible for $90 \%$ of Ghanaian marine landings (FAO, 1998), and this study revealed that fishers sell almost exclusively to local traders. It can therefore be assumed that Fante fishtraders play a pivotal roll in providing protein to a broad expanse of populations inland.

The Opening of the River: Half-ruined colonial structures rise up from a verdant beachfront alongside brick buildings, tin shacks, and endless rows of fishing canoes. The streets are dusted in red earth, crisscrossing the town in a seemingly directionless jumble. As the equatorial sun rises in the sky it bakes the earth and the air grows thick with the smell of refuse and fish. This is the town of Elmina; named so after the great castle erected by the Portuguese more than 500 years ago. Elmina is a city with rich history and old traditions.

On this day the streets are packed with excited masses. Music, dancing, and drink fill the crowd as people celebrate. It is the beginning of BaKatue, "the opening of the river", a festival which marks the beginning of the major fishing season. Fante fishers are known today for their maritime prowess, but the name BaKatue resonates from an earlier time when canoe fishers depended on rivers and estuaries.

A gentle muddy river flows through Elmina and serves as a port to countless fishers. Along its banks, brightly painted fishing canoes are crammed side by side as far as the eye can see. It is in this over-crowded estuary, on this particular day, that local fishers gather 
throughout the morning to dip bundles of herbs into the river as it meanders out to sea. It is a tradition said to make the waters fertile and bring luck to the ceremony to come.

Excitement shudders through the crowd as fishers ready the net and the time for ceremony draws near. The net will be cast three times into the estuary, and if fish are caught, the season will be a good one. Cheers erupt from the crowd as the net is cast into the water. A momentary hush falls over the masses as they draw back the net, but it returns empty. A second time the net is cast, accompanied by the roar of the crowd, and it too returns empty. A third time the net soars out over the waters and a third time the net returns empty. It is an unfortunate outcome, but not unexpected. Most years the net returns empty, but that does not stop fishers from honoring the river with herbs or crowds from gathering to witness the casting.

After the casting of the net it is time for chiefs to make their entrance. The local royalty makes their way into town in a long procession. First to arrive on foot are fishing chiefs (apofohene) and fish-trading chiefs (konkohene), clad in their finest robes and jewelry. Next to come are regional chiefs (omanhene) atop palanquins and accompanied by drummers.

The palanquins are heavy, ornately decorated platforms that are shaded with silken parcels. The large palanquins are carried on the shoulders of a dozen or more people while the chiefs wave to the passing crowd. A troop of drummers follow close behind their respective chief, playing energetic rhythms. The large, egg-shaped drums (known as talking drums) are carried atop the heads of carriers while players follow behind with drum-sticks that have the appearance of wooden pick-axes. Even at a distance the beat of the drums is deafening. The omanhene are seated atop their palanquins with stern expressions, brandishing ceremonial golden machetes and moving their arms about to the drummers beat in a kind of bladed dance. The regional chiefs emanate stoic pride as crowds look in awe at their golden jewelry, beautiful crowns, and royal grandeur.

Last to make an entrance is the paramount chief (nana omanhene). His palanquin and robes are pure white in honor of the regional paramount god, Nana Benya. The chief is accompanied by the largest group of drummers, who dance and play with energy as sweat pours from their skin. The paramount chief stands atop his palanquin looking fierce as his attendants carry him about. Nana omanhene raises his fists to the heavens and the crowd cheers. This is BaKatue, the opening of the river - the official beginning of the major fishing season.

Nana Abonoma: Waves ebb and flow across great fangs of stone as though the coast is gnawing upon the sea. Heavy surf crashes against a large, black boulder that rises from the waters a short distance from shore. The currents that run along the coast of Anomabo are quick and the surf is fierce, but the great ebony rock is never fully swallowed by the tumultuous seas. The boulder breaks the surf and serves as a natural harbor for fishers talented enough to navigate between jagged stones reaching up from the depths.

Every morning, just before sun rise, a chant pierces the still of the morning air as fishers go out to sea:

"Nana Abonoma myereka"

"Ma yenya nam"

"Ma yenkum nam bebae"

The fishers stand in line with one another atop their canoe and pay respect to the ebony giant that guards the coast and stills the waters within. They clap their hands and jump in unison as they pass by the great, black stone. They pay respect to the entity that provides 
fish and safety from the raging sea. They give respect to the stone where gods reside. Again, the fishers sing with deep beautiful voices as one, calling out to the gods in prayerful respect:

"Nana Abonoma myereka" - Elder Abonoma, we are going

"Ma yenya nam" - Help us catch

"Ma yenkum nam bebae" - Help us catch plenty

It is known among the fishers that it is necessary to pay homage to the gods of the ocean. The high seas are dangerous and the catch is far from certain. For generations Nana Abonoma has stood watch over the village; granting blessings to fishermen. The town once called itself by the same name, but as colonial powers took hold of the coast and corrupted true names, the village of Abonoma became the village of Anomabo. Today Anomabo still carries its colonial name, but the fishers have not forgotten their ancestral god or the true name of their village. The very existence of Anomabo hinges upon the bounty provided by the ocean. It is no wonder that the local god of the sea is still remembered. Even as many old ways are lost to modernity, they remain faithful children of Nana Abonoma.

It is from the ocean that the Fante people survive. And so long as there are fish in the sea, Fante fishers will brave the surf to catch them. And so long as mighty fishers ride out bravely to the horizon, there will surely be those who pay respect to Nana Abonoma: the god of the sea.

Tuesday: It is quiet. The waves crash and the cock crows, but no chants are carried along on the cool morning breeze. The usual clamor that the beach market brings is quelled by silence. Where are the fishers and their baskets of fish? Where are the trades-women bartering for their share of the catch? Save for a few huddled clusters of fishers repairing their nets and mending canoes, the usually frenzied beach is empty and calm. Elsewhere in the village business goes about as normal. Canoes take shape, repairmen mend engines, and shop-keepers hawk their wares.

It is the tradition of honoring Tuesday which silences the beaches for a day. It is said that on Tuesday that the gods replenish the sea. Once a week, fishermen remain on shore and allow the ancestors to nurse the ocean back to health. It is known among the seafaring men of Anomabo that to venture out to sea on Tuesday is disrespectful to the gracious entities which provide rich seas. It is far too risky to brave the unpredictable ocean without the gods. And only the most stubborn or desperate of fishers take to the surf on Tuesday.

Come Sunday morning many fishers will find their way into a Christian church, but more often than not, they will be at sea. Christianity is the dominant religion, but the old gods of the sea are best respected by those who brave raging waters. No other profession observes Tuesday as a sacred day. It is a tradition observed solely by the Fante fishers.

\section{Discussion:}

This study suggests that Fante-speaking people of West Africa are highly dependent on ocean resources as the basis of their nutrition, economy, and cultural identity. West African fish stocks are overexploited by industrial fisheries (Pauly et al., 2005) which, as this study has shown, directly compete with artisanal fishers. Under such circumstances, there appears to be good reason to recognize the right of groups to guard themselves against the intrusions of the outside world and to determine their own destiny (Kukathas, 1992). Granting those who live from the sea the legal right to defend their resources also grants them the right to defend their culture. The only ethical option available to the West African 
fisheries situation is to empower artisanal fishers against the current trend of irresponsible exploitation.

In 1996, community-based fisheries management was introduced in both inland and marine fisheries in Ghana. Moree was the first coastal village where a Community Based Fishery Management Committee (CBFMC) was introduced. The CBFMC programmed in Moree achieved some results in improving beach hygiene and regulating dynamite fishing (Koranteng, 2000). But the current system offers few avenues for dialogue with higher-up government entities, and the CBFMC has virtually no power to advance its own agenda. If user groups are not legally empowered, their negotiating position versus that of the government is consequently comparatively low, or as Chirwa (1997) points out: "The local user communities are the recipients rather than the initiators of decisions. They, themselves, are managed, together with their resources"(pp. 23). It can be argued that this type of co-management cannot be viewed as co-management in a strict sense, as in reality it is simply "top-down" management.

Fishers do not easily accept the command and control that impersonal government intrusion brings. This lack of acceptance is exacerbated when what they are being told does not make sense in terms of the way they see problems, know their industry, and have learned to understand nature. This is the problem that co-management is uniquely suited to address. Co-management is not so much about the rules per se as it is about the communicative and collaborative process through which rules are formed: who participates, how debates are structured, how knowledge is employed, how conflicts of interest are addressed, and how agreements are reached (Jentoft et al., 1998). A collaborative system which includes user populations have the potential of managing resources and empowering artisanal fishers. If local people are granted the means and authority to manage their resources, they will do so for the benefit of the community.

Examples of successful co-management support the notion that people linked by a strong sense of place, culture, community, and cause can self-regulate resources for the long-term good of the collective (Jentoft et al., 1998). In the Chile (as well as in the Cook Islands and Alaska), artisanal fisheries and local cooperatives have been granted ownership of the foreshore and intertidal areas, allowing them to exclude other fishermen and optimally harvest the resources they manage in an ecologically sustainable fashion (Castilla et al., 1998). Resources held by users in common can be withheld by other members through a group decision and can thus be employed as a sanction against users who break the rules. A modern example of this is the local fisheries of Japan (Jentoft et al., 1998). Co-management can be a powerful and successful mechanism for the preservation of ocean resources and fishing communities if provided with sufficient government support.

In most cases studied (Jentoft et al., 1998), co-management arrangements have been established in response to resource depletion. Under such circumstances it would seem critically important that governments should not leave their local partners with management responsibilities that they are incapable of shouldering, be it for reasons of lack of knowledge or lack of resources. Indigenous knowledge among fishers is often related to the fish resources and is concentrated on aspects that are relevant to fish capture, and does not to any large extent comprise the biology of the resources (i.e. spawning grounds, nurseries, etc.). This is why collaboration involving both artisanal fishing communities and government bureaucracy is absolutely necessary. Governments must provide accurate ecological information in order for local populations to make educated decisions regarding resource management. 
Given the nature of the problems and the mobility of both resources and fishermen, this work must not only be encouraged within Ghana, but also extended to West Africa as a whole (Campredon \& Cuq, 2001). The Economic Community of West African States (ECOWAS) could serve as a powerful medium for regional co-management implementation. However, such regional cooperation is likely to face opposition. Budget deficits, growing debt, and difficulties in developing exports of agricultural commodities or manufactured products are forcing some West African governments to consider fishery license fees as the only reliable and quick source of hard currency revenues (Kaczynski \& Looney, 2000). For example, $27 \%$ of Mauritania's state budget is funded by fishing access fees (UNEP, 2002). It is a daunting prospect to empower the many West African coastal communities. But given the scale and precarious nature of the situation, if we are to preserve ocean resources and the people who rely upon them, change must be large in scope.

\section{Conclusion:}

Competition among artisanal and commercial fisheries increases the stress placed on the environment and threatens marine stocks that coastal populations rely upon. Given the "fishing down the food web" phenomena and related trends, it appears rather urgent to action is needed to implement the reforms long proposed by fisheries scientists and economists: radically reduce fishing capacity (Mace, 1997). Notably, one solution is to abolish government subsidies that keep otherwise unprofitable fisheries afloat (Munro \& Sumaila, 2002), and strictly enforce various equipment restrictions (Chuenpagdee et al., 2003). Additionally, there must be reserve areas set aside in order to promote the overall health of West African marine ecosystems.

Marine Protected Areas (MPAs) will have a key role to play in integrated coastal zone management (ICZM) in several respects. First, they are needed to maintain healthy population levels of vulnerable species from overfishing so that they can subsequently help population levels outside the protected area to recover (Roberts, 1995). To this end, MPAs should not be considered as isolated units but rather as part of a whole within which they are complementary to other areas of the coastal zone (Campredon \& Cuq, 2001). "No-take" marine reserves will have to be instituted, not as scattered and small concessions to appease conservationist pressure, but as a legitimate and obvious management tool (Pauly et al., 2005).

Such measures may not permit an increase in future landings, that is, to continue meeting an ever-increasing human demand (Pauly et al., 2003). Rather, these measures may allow us to sustain what we have, and that which we are in the process of losing (Dulvy et al., 2003). Unsustainable industrial fishing is the primary factor behind the intensification of food security issues that reduced per capita fish supplies in developing countries creates (Garcia \& de Leiva Moreno, 2003). The preservation of marine stocks is therefore not only a question of environmental conservation but also social welfare. If the formation of marine policy is to be successful it must take into consideration the human element.

Natural scientists often prefer to ignore the politics of human societies. While this attitude is by no means universal, it does tend to appear in the policy recommendations of natural scientists. They frequently ignore important determinants of human behavior, such as the political forces that influence what and how people learn, the political forces that influence what events are or are not considered crises, and what things are and are not considered to be property. Such blind spots may cause scientists to provide advice or formulate policy that is either grossly inadequate, or open to disastrous misuse (Ludwig et al., 1993; Gunderson, 1999). Those who live from the sea are most vulnerable to the ramifications of the global fisheries crisis. Therefore, local resource users should be involved in regulatory decision 
making, implementation, and enforcement (Jentoft et al., 1998). A collaborative comanagement approach will enable the creation of policy that accounts for the needs of coastal populations while still promoting the health of marine ecosystems.

Co-management must be enacted on a regional scale in order to ensure the promotion of viable fish stocks and the survival of traditional fishing cultures. ECOWAS could be a powerful mechanism for the implementation of co-management on a massive scale. However, regional cooperation is likely to face opposition as many nations have grown dependent on fisheries revenues. The road toward sustainability is not without hurdles, but if traditional fishing cultures are to survive, change must be enacted - and quickly.

"If one thinks that coastal communities are doomed and that it is just a matter of time before the traditional culture of fishing is history, co-management seems hardly worth the effort" (Jentoft et al., 1998 pp. 12). But if ethics holds any sway in modern fisheries policy, there must be change. Current practices of irresponsible and unsustainable fishing are destroying marine stocks (Pauly et al., 2005). And as fish stocks decline, traditional fishing people, such as the Fante, are presented with a situation in which the basis of their diet, economy, and culture is threatened by industrial efforts.

If commercial fisheries maintain this course and marine resources crumble under the strain of industry, Fante fishing traditions will pass away into the analogues of history. Change is the only ethical option available to humanity at this juncture. Without well-informed and dramatic policy change, we will witness the destruction of marine resources and subsequently the annihilation of traditional fishing peoples in West Africa.

\section{Acknowledgements:}

I would like to express my sincere appreciation to Dr. Kofi Agorsah, without whom this work would not have been possible. I offer my gratitude to Philip Atta-Yawson, my translator, and William Schaffer of Arizona State University for their assistance and advice throughout the course of this research. Thanks are due to the Ghanaian Fisheries Ministry of Cape Coast for providing translations of local names and data regarding commercial practices. And lastly, I would like to thank the Ronald E. McNair Scholars Program for funding this work. 


\section{Works Cited}

Acheampong A. (1997) Coherence between EU fisheries agreements and EU development cooperation: the case of West Africa. (ECDPM Working Paper No. 52). Maastricht: ECDPM.

Alder J. \& Sumaila U. (2004) Western Africa: a fish basket of Europe past and present. Journal of Environment and Development, 13, 156-178.

Atta-Mills J., Alder J. \& Sumaila U. (2004) The unmaking of a regional fishing nation: The case of Ghana and West Africa. Natural Resources Forum, 28, 13-21.

Awity L., Koranteng K. \& Quist M. (1996) The way forward for fisheries associations in Ghana. The Fishermen, 3, 4-7.

Boujou S. (2000) Peche continentale et migration: controle politique et controle social des migrations de peche nationaux dans la societe guineene. In: Les peche piroguieres en Afrique de l'Ouest. Puvoirs, mobilites, marches (ed. Chauvea J., Jul-Larsen E. \& Chaboud C. ) Paris, Karthala.

Campredon P. \& Cuq F. (2001) Artisanal fishing and coastal conservation in West Africa. Journal of Coastal Conservation, 7, 91-100.

Castilla J., Manriquez P., Alvarado J., Rosson A., Pino C., Espoz C., Soto R., Oliva D., Defeo O. (1998) Artisanal "Calets" as units of production and co-managers of benthic invertebrates in Chile. Can. Spec. Publ. Fish. Aquat. Sci., 125, 407-413.

Chirwa W. (1997) The Lake Malombe and Upper Shire River fisheries co-management program: an assessment. In Norman et al. 1998.

Christensen J. (1977) Motor power and women power: Technological and economic change among the Fanti fishermen of Ghana. In: Those who live from the sea: A study of maritime anthropology, edited by M. Estellie Smith, 71-95. New York, West Publishing.

Christensen V. (1998) Fishery-induced changes in a marine ecosystem: insight from models of the Gulf of Thailand. Journal of Fish Biology, 53, 128-142.

Chuenpagdee R., Morgan L., Maxwell S., Norse E. \& Pauly D. (2003) Shifting gears: Assessing collateral impacts of fishing methods in the U.S. waters. Frontiers Ecol. 
Environ., 10, 517-524.

Cury P. \& Roy C. (2002) Environmental forcing and fisheries resources in Cote d'Ivoire and Ghana : Did something happen? In: J. McGlade, P. Cury, K. Koranteng \& N. HardmanMountford (eds) The Gulf of Guinea large marine ecosystem. 241-260. Amsterdam, Elsevier Science.

Delauney, K. (1991) Artisanal Maritime Fisheries in Côte d'Ivoire. In: Haakonsen, J. and Diaw, M. C. (Eds.) Fishermen's Migrations in West Africa. IDAF/WP/36.

Cotonou: FAO Programme for Integrated Development of Artisanal Fisheries in West Africa.

Delauney, K. (2000) Vridi (Côte d'Ivoire). Histoire d'une révélation. In: Chauveau, J.-P., Jul-Larsen, E. and Chaboud, C. (Eds.) Les pêches piroguières en Afrique de I'Ouest. Puvoirs, mobilités, marchés. Paris: Karthala.

Denney N., Jennings S. \& Renolds J. (2002) Life-history correlates of maximum population growth rates in marine fishes. Proc. R. Soc. B, 269, 2229-2237.

Diaw M. (1992) Enthnogenesis, mobility and politics in the history of West African canoe fishermen. In: Tvedten I. \& Hersoug B. (Eds) Fishing for development: Small-scale fisheries in Africa. Uppsala, The Nordic Africa Institute.

Dulvy N., Sadovy Y. \& Reynold J. (2003) Extinction vulnerability in marine populations. Fish and Fisheries, 4, 25-64.

Food and Agriculture Organization of the United Nations (FAO) (1997) Review of the state of the world fishery resources: Marine fisheries, Eastern Central Atlantic. Fisheries Circular no. 920 FIRM/C920. Rome: FAO.

Food and Agriculture Organization of the United Nations (FAO) (2000). FISHSTAT Plus: Universal Software for Fishery Statistical Time Series (Version 2.3). Rome: FAO, Fisheries Department, Fishery Information, Data and Statistics Unit. Retrieved April 23, 2003, from http://www.fao.org/fi/statist/statist.asp

FAO/Fishery Committee for Eastern Central Atlantic. Report of the third session of the 
Scientific Sub-Committee, Lome, Togo. 24-26 February, FAO fisheries report, No. 750, Accra, FAO, 2004, pp. 35.

Garcia S. \& de Leiva Moreno I. (2003) Global overview of mature fisheries. In: Responsible fisheries in the marine ecosystem (ed. Sinclair M. \& Valdimarsson G.), 1-24. Rome, FAO Gunderson L. (1999) Resilient management: comments on "Ecological and social dynamics in simple models of ecosystem management" by S.R. Carpenter, W.A. Brock, P. Hanson. Conservation Ecology, 3(2): 7. (online) http://www.consecol.org/vol3/iss2/art7

Ihedru O. (1995) The political economy of Euro-African fishing agreements. Journal of Developing Areas, 30, 63-9.

Intergovernmental Oceanographic Commission (IOC) (1997) IOC Regional Workshop for Member States of West Africa-GODAR-VI. Global Oceanographic Data Archaeology and Rescue Project. Workshop Report No. 136. Intergovernmental Oceanographic Commission (IOC), Accra.

Jentoft S., McCay B., Wilson D. (1998) Social theory and fisheries co-management. Marine Policy, 22, 423-436.

Jorion P. (1988) Going out or staying home: Seasonal movements and migration strategies among Xwla and Anlo-Ewe fishermen. Maritime Anthropological Studies, 1, 129-155.

Kaczynski V. \& Fluharty D. (2002) European policies in West Africa: who benefits from fisheries agreements?. Marine Policy, 26, 75-93.

Kaczynski V. \& Looney S. (2000) Coastal resources as an engine of economic growth and reduction of poverty in West Africa: Policy considerations. Coastal Management, 28, 235248.

Koranteng K. (1984) A trawling survey off Ghana. CECAF/TECH/84/63. Dakar, Senegal. CECAF Project (FAO). Dakar, Senegal.

Koranteng K. (1989) The sardinella (herring) fishery in Ghana: The past, recent developments, and the years ahead. Tema, Ghana: Fisheries Department Research and Utilization Branch. 
Koranteng K. (2000) Biophysical study of marine and fishery resources at Moree, Ghana. PCE-Report, MacArthur Foundation. Tema, Marine Fisheries Research Division. Korentang K. (2001) Structure and dynamics of demersal assemblages on the continental shelf and upper slope off Ghana, West Africa. Marine Ecology Progress Series, 220, 1-12. Koranteng K. \& Pauly D. (2004) Long-term trends in demersal fishery resources of Ghanaian response to fishing pressure. In: M. Palomares \& Pauly D. (eds) West African marine ecosystems: models and fisheries impacts. Fisheries Centre, UBC, Vancouver, Fisheries Centre Research Reports, 12, 75-80.

Kukathas C. (1992) Are there any cultural rights?. Political Theory, 20, 105-139.

Kwei E. (1961) Recent developments in the canoe fisheries in Ghana. Ghana Journal of Science, 1, 29-35.

Laurans M., Gascuel D., Chassot E., \& Thiam D. (2004) Changes in the Trophic Structure of Demersal Communities in West Africa in the Three Last Decades. Aquatic Living Resources, 17, 163-173.

Law R. (1989) Between the sea and the lagoons: The interaction of maritime and inland navigation on the pre-colonial slave coast. Cahiers d'Etudes Africaines, 114, 209-237.

Lawson R. \& Kwei E. (1974) African entrepreneurship and economic growth: A case study of the fishing industry in Ghana. Accra, Ghana University Press.

Ludwig D.,Walker B., Holling C. (1997) Sustainability, stability and resilience. Conservation Ecology (online) 1(1): 7 http://www.consecol.or/vol1/iss1/art7.

Mace P. (1997) Developing and sustaining world fisheries resources: the state of fisheries and management. In: Proc $2^{\text {nd }}$ World Fisheries Congr. (ed. D.H. Hancock, D.C. Smith, A. Grant \& J.P. Beumer), 1-20, Collingwood, Australia: CSIRO Publishing.

Marquette C., Koranteng K., Overa R. \& Aryeetey E. (2002) Small-scale fisheries, population dynamics, and resource use in Africa: The case of Moree, Ghana. Journal of the Human Environment, 31, 324-336.

Matthews D. (1993) Controlling common property: regulating Canada's east coast fishery. 
University of Toronto Press, Toronto, 1993, p. 5.

Munro G. \& Sumaila U. (2002) Subsidies and their potential impact on the management of the ecosystems of the North Atlantic. In: Fisheries impacts on North Atlantic ecosystems: evaluations and policy explorations (ed. T. Pitcher, U. Sumaila \& D. Pauly), 10-27. University of British Columbia Fisheries Centre Research Report, 9(5). See www.fisheries.ubc.ca

Nicholas N. (1999) Field testing of methodologies for evaluating post harvest losses of artisanal fisheries in West Africa: a case study of Kormantse fishing community, Central Region, Ghana. Fisheries Report. Wenchi Farm Institute.

Njock J. \& Westlund L. (2010) Migration, resource management and global change: Experiences from fishing communities in West and Central Africa. Marine Policy, 34, 752760.

Overa R. (1998) Partners and competitors: Gendered entrepreneurship in Ghanaian canoe fisheries. Doctoral dissertation. Bergen: Department of Geography, University of Bergen. Overa R. (2001) Institutions, mobility and resilience in the Fante migratory fisheries of West Africa. Bergen, Chr. Michelsen Institute.

Pauly D. \& Watson R. (2003) Running out of fish. Scientific American, 289, 35-39.

Pauly D., Alder J., Bennett E., Christensen V., Tyedmers P. \& Watson R. (2003) World The future for fisheries. Science, 302, 1359-1361.

Pauly D., Watson R. \& Alder J. (2005) Global trends in world fisheries: impacts on marine ecosystems and food security. Phil. Trans. R. Soc. B, 360, 5-12.

Perry R. \& Sumaila U. (2003) Marine ecosystem variability and human community responses: the example of Ghana, West Africa. Sea Around Us Project, Fisheries Economics Research Unit. University of British Columbia.

Pinnegar J., Jeannings S., O'Brien M., Polunin V. (2002) Long-term changes in the trophic level of the Celtic Sea fish community and fish market price distribution. Journal of Animal Ecology, 39, 377-390. 
Roberts C. (1995) Effects of fishing on the ecosystem structure of coral reefs. Conservation Biology, 9 ,988-995.

Sadovy Y. \& Cheung W. (2003) Near extinction of a highly fecund fish: Trouble among the croakers. Fish Fish., 4, 86-99.

Ursin E. (1973) On the prey preference of cod and dab. Medd. Danm. Havunders. N.S., 7, 85-98.

United Nations Environment Program (UNEP). (2002) Environmental impact of trade liberalization and trade-linked measures in the fisheries sector. Nouadhibou, Mauritania: National Oceanographic and Fisheries Research Centre.

Valtysson H. \& Pauly D. (2003) Fishing down the food web: an Icelandic case study. In: Competitiveness within the global fisheries (eds) E Guomundsson \& H. Valtysson, 12-24. Akureyri, University of Akureyri.

Walker B. (2001) Sisterhood and seine-nets: Engendering development and conservation in Ghana's marine fishery. Professional Geographer, 53, 160-177. 